Journal of Technology and Social for Community Service (JTSCS)

Vol. 2, No. 2, September 2021, page-page. 48 53

P-ISSN: 2723-455X

E-ISSN: 2723-2026

available online at: https://ejurnal.teknokrat.ac.id/index.php/teknoabdimas

\title{
PELATIHAN PEMBUATAN PERANGKAT AJAR SILABUS DAN RPP SMK PGRI 1 LIMAU
}

\author{
Rachmi Marsheilla Aguss ${ }^{1}$, Dina Amelia ${ }^{2}$, Zaenal Abidin ${ }^{3}$, Permata $^{4}$ \\ Universitas Teknokrat Indonesia ${ }^{1234}$
}

mail : rachmi.ma@teknokrat.ac.id ${ }^{1}$, amelia.dina@teknokrat.ac.id ${ }^{2}$, zabin@teknokrat.ac.id ${ }^{3}$,permata@teknokrat.ac.id ${ }^{4}$

\begin{abstract}
Planning can provide guidelines for the implementation of learning, so that it is right on target and effective. One of the goals of educational planning that is very meaningful made by teachers as educational directors is the Syllabus and Learning Implementation Plans and Plans (RPP). Teachers of SMA/Vocational High School (SMK) PGRI 1 Limau are the right target for community service activities considering that the school has not had sufficient technical training. The purpose of this dedication activity is to train and motivate teachers to be able to develop the perfect syllabus and lesson plans. The lesson plan (RPP) is a more specialized planning tool than the syllabus. This educational implementation plan is designed to guide teachers in teaching so that they are not far from educational goals. Recognizing the importance of planning this lesson, teachers should not teach without planning. There is also feedback that shows that the training is suitable with the needs of increasing teacher professionalism and is optimistic that the training can be achieved. Supporting energy for training in the form of space or supporting facilities is sufficient so that the training can run easily, well, on time, and fun. Participants are very supportive of further training. Keywords: Building teacher professionalism with syllabus training, lesson plans, 2013 curriculum.
\end{abstract}

Keywords: Training, Development, Syllabus, Learning Implementation Plan.

\begin{abstract}
Abstrak
Perencanaan dapat memberikan pedoman bagi pelaksanaan pembelajaran, sehingga tepat sasaran serta efektif. Salah satu tujuan dari perencanaan pendidikan yang sangat berarti terbuat oleh guru selaku pengarah pendidikan merupakan Silabus serta Rencana dan Rencana Pelaksanaan Pembelajaran (RPP). Guru- guru SMA/ Sekolah Menengah Kejuruan(SMK) PGRI 1 Limau ialah sasaran target aktivitas pengabdian kepada masyarakat yang pas mengingat mereka pihak sekolah belum sempat memperoleh tutorial teknis yang mencukupi. Tujuan aktivitas dedikasi ini merupakan buat melatih serta memotivasi guru supaya sanggup menyusun silabus serta RPP yang sempurna. Rencana pelaksanaan pembelajaran( RPP) merupakan perlengkapan perencanaan yang lebih khusus daripada silabus. Rencana penerapan pendidikan ini dirancang buat memandu guru dalam mengajar supaya tidak jauh dari tujuan pendidikan. Menyadari pentingnya merencanakan pelajaran ini, guru hendaknya tidak mengajar tanpa perencanaan. Ada pula umpan balik didapat menampilkan bahwa pelatihan cocok dengan kebutuhan kenaikan profesionalisme guru serta optimis pelatihan bisa tercapai. Energi dukung pelatihan berbentuk sarana ruang ataupun sarana pendukung lumayan mencukupi sehingga pelatihan dapat berjalan dengan mudah, baik, pas waktu, serta mengasyikkan. Partisipan sangat menunjang terdapatnya pelatihan lanjutan.
\end{abstract}

Kata Kunci: Pelatihan, Pengembangan, Silabus, Rencana Pelaksanaan Pembelajaran. 


\section{To cite this article:}

Rachmi Marsheilla Aguss, Dina Amelia, Zaenal Abidin, Permata. (2021). PELATIHAN PEMBUATAN PERANGKAT AJAR SILABUS DAN RPP SMK PGRI 1 LIMAU. Journal of Technology and Social for Community Service (JTSCS), Vol(2), 48-54.

\section{PENDAHULUAN}

Pendidikan adalah proses untuk membuat manusia menjadi lebih baik, lebih terampil, dan lebih terampil (Sudirman, 2020). Untuk mencapai tujuan tersebut tentunya diperlukan suatu strategi yang disebut dengan strategi pembelajaran. Dalam strategi pembelajaran terdapat tiga hal pokok yaitu perencanaan, pelaksanaan dan evaluasi. Perencanaan dapat memberikan pedoman bagi pelaksanaan pembelajaran, sehingga tepat sasaran dan efisien (Fahrizqi, E. B., Aguss, R. M., \& Yuliandra, R. 2021). Kebudayaan dalam warga pula ikut memberikan pengaruh yang sangat besar untuk pengorganisasian kurikulum (Fernandes, R. 2019). Salah satu bagian dari perencanaan pembelajaran yang sangat penting dibuat oleh guru sebagai pengarah pembelajaran adalah Silabus dan Rencana Pelaksanaan Pembelajaran (RPP). Silabus menerangkan tujuan yang wajib dicapai untuk menggapai tujuan pendidikan serta tata cara yang hendak digunakan. Tidak hanya itu, silabus pula memuat metode evaluasi yang digunakan untuk menguji tingkatan keberhasilan pendidikan. Silabus merupakan seperangkat rencana serta pengaturan aktivitas pendidikan, pengelolaan kelas serta penilaian hasil belajar (Nurdiana, 2017). Rencana Pelaksanaan Pembelajaran (RPP) adalah alat perencanaan yang lebih spesifik daripada silabus. Rencana pelaksanaan pembelajaran ini dirancang untuk memandu guru dalam mengajar agar tidak jauh dari tujuan pembelajaran. Menyadari pentingnya merencanakan pelajaran ini, guru hendaknya tidak mengajar tanpa perencanaan.

Banyak aspek yang memastikan mutu pembelajaran, tetapi guru senantiasa ditetap selaku aspek penentu utama, sebab guru yang sangat berpengaruh dan memegang kendali pendidikan, memastikan arah pencapaian dan tujuan pendidikan, serta mengelola pendidikan siswa (Amir, 2013). Sesuai dengan tujuan pendidikan dalam pelaksanaanya maka disusunlah sebuah kurikulum. Menurut UU No. 20 Tahun 2003 pasal 1 ayat (19), yang dimaksud dengan kurikulum adalah seperangkat rencana dan pengaturan mengenai tujuan yang didalamnya terdapat isi dan materi pembelajaran serta metode yang digunakan sebagai pedoman dalam pelaksanaan kegiatan pembelajaran untuk mencapai tujuan pendidikan nasional. Menghadapi permasalahan tersebut pemerintah Republik Indonesia periode 2014- 2019 melakukan revisi kurikulum 2013 dengan progres intinya pendidikan abad 21 (Fernandes, R. 2019).

Kurikulum 2013 menuntut siswa untuk dapat melaksanakan pembelajaran secara aktif dan kreatif. Perihal tersebut di dalam kurikulum 2013 buat mewujudkan implementasinya para guru dituntut secara baik merancang pendidikan efisien serta bermakna, mengorganisasikan pendidikan, memilah pendekatan pendidikan yang pas, memastikan prosedur pendidikan, serta pembuatan kompetensi secara efisien, dan menetapkan kriteria untuk keberhasilan pembelajaran (Mulyasa, 2017). Untuk dapat mencapai tujuan tersebut maka diperlukan suatu perencanaan pembelajaran yang dapat menumbuhkan minat belajar siswa dikelas. Dalam hal ini, guru memiliki peran yang sangat penting terutama dalam pembuatan dan pengembangan RPP dan silabus, karena dari rencana yang dibuat oleh guru tersebut pembelajaran menjadi lebih terarah. SMK PGRI 1 Limau merupakan salah satu sekolah yang harus mengembangkan RPP dan Silabus yang sesuai dengan kurikulum 2013. Silabus adalah sekumpulan rencana dan pengaturan kegiatan pembelajaran, pengelolaan kelas, dan penilaian hasil belajar. Silabus bermanfaat sebagai pedoman sumber daya dasar dalam pengembangan pembelajaran selanjutnya, mulai dari pembuatan RPP, pengelolaan kegiatan pembelajaran, dan pengembangan sistem penilaian. Silabus membagikan arah tentang program apa yang wajib dicapai guna mencapai tujuan pendidikan serta metode semacam apa yang hendak digunakan. Tidak hanya itu silabus pula memuat metode evaluasi untuk menguji sejauh mana keberhasilan pendidikan (Sommeng,A. 2019). Guru harus mampu berperan sebagai desainer (sebagai perencana), implementor (sebagai pelaksana), dan evaluator (sebagai penilai) kegiatan pembelajaran. Guru merupakan faktor yang paling dominan karena di tangan guru keberhasilan pembelajaran dapat dicapai. Kualitas pengajaran guru secara langsung maupun tidak langsung dapat mempengaruhi kualitas pembelajaran secara umum.

Pengembangan RPP di SMK PGRI 1 Limau hingga kini belum diterapkan. Situasi ini dapat diketahui melalui wawancara dengan para guru di SMK PGRI 1 Limau yaitu didapatkan informasi bahwa mereka belum mengembangkan RPP sesuai kurikulum 2013 tetapi masih menggunakan RPP lama yang sudah ada. Hal ini terjadi karena guru merasa bingung dan kesulitan dalam menyusun RPP karena belum terlalu paham terhadap pembuatan serta pengembangan silabus dan RPP. Sehingga kemampuan guru menyusun silabus dan RPP yang lengkap dan sistematis masih sangat kurang. Untuk meningkatkan kemampuan guru menyusun silabus dan RPP 
yang lengkap dan sistematis, telah dilakukan pelatihan pembuatan silabus dan RPP bagi guru SMK PGRI 1 Limau Tanggamus.

Hal ini bertujuan untuk memberikan gambaran tentang pengembangan RPP yang sesuai dengan kurikulum 2013. Dalam kurikulum 2013 pengembangan silabus tidak lagi dilakukan oleh guru tetapi telah disiapkan oleh tim pengembangan kurikulum, baik di tingkat pusat maupun daerah. Kegiatan ini dilakukan karena adanya kendala pada guru SMK PGRI 1 Limau yang belum menggunakan RPP sesuai kurikulum 2013. Selama ini guru hanya menggunakan RPP yang sudah ada pada tahun-tahun sebelumnya, bahkan mereka langsung mengunduh secara online. Kegiatan pelatihan ini berupa bagaimana menyusun silabus dan RPP sesuai dengan kurikulum 2013, bagaimana cara menggunakan metode yang baik, hingga evaluasi dalam kegiatan pembelajaran. Kemudian diakhir kegiatan pelatihan peserta dilatih untuk menyusun silabus dan RPP sesuai dengan bidang studi masing-masing.

\section{METODE PELAKSANAAN \\ Tempat dan Waktu}

Pelaksanaan pelatihan pembuatan silabus dan rencana pelaksanaan pembelajaran dilaksanakan diaula SMK PGRI 1 yang terletak dikecamatan Limau kabupaten Tanggamus. Kegiatan pelatihan ini dimulai sejak bulan Februari sampai dengan Juni 2021.

\section{Khalayak Sasaran}

Sasaran dalam kegiatan pelatihan ini adalah guru-guru yang ada di SMK PGRI 1 Limau. Jumlah keseluruhan guru yang ada di SMK PGRI 1 Limau ada 20 orang yang berasal dari backgorund pendidikan sarjana yang berbeda-beda dari masing-masing guru mata pelajaran tersebut.

\section{Metode Pengabdian}

Dalam kegiatan Pengabdian Kepada Masyarakat ini menggunakan beberapa berbagai pendekatan, yaitu diantaranya menggunakan metode ceramah dalam penyampaian materi-materi pelatihan, diskusi secara langsung, kemudian praktek pembuatan silabus dan RPP. Teknik dalam mengumpulkan data digunakan prestest terlebih dahulu kemudian post test. Target aktivitas ini merupakan guru-guru SMK PGRI 1 Limau. Bersumber pada informasi yang sempat dikumpulkan, bahwa guru-guru disekolah tersebut belum meningkatkan perangkat ajar namun masih memakai perangkat ajar yang lama belum memakai perangkat ajar yang baru. Perihal ini terjalin sebab guru merasa bimbang serta kesulitan dalam menyusun perangkat ajar. Sehingga keahlian guru untuk menyusun perangkat ajar seperti silabus dan RPP yang sudah lengkap serta sistematis masih kurang. Untuk menambah keahlian guru dalam menyusun silabus serta RPP yang sudah lengkap serta sistematis, sudah dicoba pelatihan untuk pembuatan silabus serta RPP untuk guru-guru SMK PGRI 1 Limau. Aktivitas dedikasi ini diiringi oleh guru SMK PGRI 1 Limau. Secara universal, sekolah masih terletak pada pengembangan pemakaian Kurikulum 2013.

\section{HASIL DAN PEMBAHASAN}

Aktivitas pelatihan dilakukan pada bulan maret hingga bulan april, setelah itu ditindak lanjuti dengan aktivitas pendampingan (kunjungan) kesekolah target untuk memantau perkembangan pembuatan silabus dan RPP yang dilaksanakan peserta. Secara universal, aktivitas pelatihan berjalan lancar. Penulis memperoleh informasi umpan balik dari partisipan pelatihan untuk membagikan evaluasi dari 1 (mutu terendah) sampai 5 (mutu paling tinggi) terhadap aspek pelatihan sebagaimana disajikan pada Tabel 1 berikut.

Tabel 1. Umpan Balik Peserta Pelatihan

\begin{tabular}{|l|l|c|c|}
\hline No & \multicolumn{1}{|c|}{ Nama } & Pretes & Postes \\
\hline 1. & Ahmad Yani, S.Pd. & 70 & 81 \\
\hline 2. & Evi Sulismawati, S.Kom. & 72 & 85 \\
\hline 3. & Jaka Afrila, S.Pd. & 72 & 86 \\
\hline 4. & Juni Ariyanti, S.Pd. & 71 & 83 \\
\hline
\end{tabular}




\begin{tabular}{|c|l|c|c|}
\hline 5. & Purwaningsih & 73 & 87 \\
\hline 6. & Mimin Tarsih, S.Kom. & 75 & 88 \\
\hline 7. & Mutoharoh, S.Pd. & 77 & 89 \\
\hline 8. & Piki Nahrido, S.Pd. & 70 & 83 \\
\hline 9. & M.Eko Setiawan, S.Pd. & 74 & 85 \\
\hline $\mathbf{1 0 .}$ & Agus Setiawan, S.E. & 75 & 86 \\
\hline 11. & M..Maulana & 72 & 84 \\
\hline 12. & Khoirotu Alkahfi Qurun,S.Ag & 73 & 86 \\
\hline 13. & Titi Setianingsih, S.Pd. Total & 73 & 85 \\
\hline 14. & Surahmat & 76 & 88 \\
\hline \multicolumn{2}{r|}{ Rata - Rata } & 1022 & 1196 \\
\hline & Nilandar Deviasi & 73,0714 & 85,429 \\
\hline \multicolumn{2}{r|}{ Nilai Maksimal } & 2,129077 & 2,208873 \\
\hline & 70 & 81 \\
\hline
\end{tabular}

Pada Tabel 1 di atas, terlihat bahwa partisipan merespon baik dengan adanya pelatihan. Terdapat 2 tes yang dilakukan yaitu tes awal dan tes akhir, tes awal mendapatkan total yang berjumlah 1022 dengan rata-rata 73,0714 yang memiliki nilai terendah 70 dan nilai terbesar yaitu 77 sedangkan untuk tes akhir mendapatkan total nilai 1196 dengan rata-rata 85,429 yang memiliki nilai terendah 81 dan nilai tertinggi 89. Partisipan berkomentar jika pelatihan cocok dengan kebutuhan kenaikan profesionalisme guru serta optimis dengan tujuan pelatihan bisa tercapai. Bagi partisipan pelatihan berjalan sangat baik, tepat waktu, serta mengasyikkan. Energi dukung pelatihan berbentuk sarana ruang ataupun sarana pendukung lumayan mencukupi sehingga pelatihan dapat berjalan dengan mudah. Partisipan sangat menunjang terdapatnya pelatihan lanjutan sehingga mendapatkan hasil yang lebih meningkat dibandingkan sebelumnya. Adapun Diagram batang tes awal dan tes akhir yang dapat disajikan dalam pelatihan sebagai berikut.

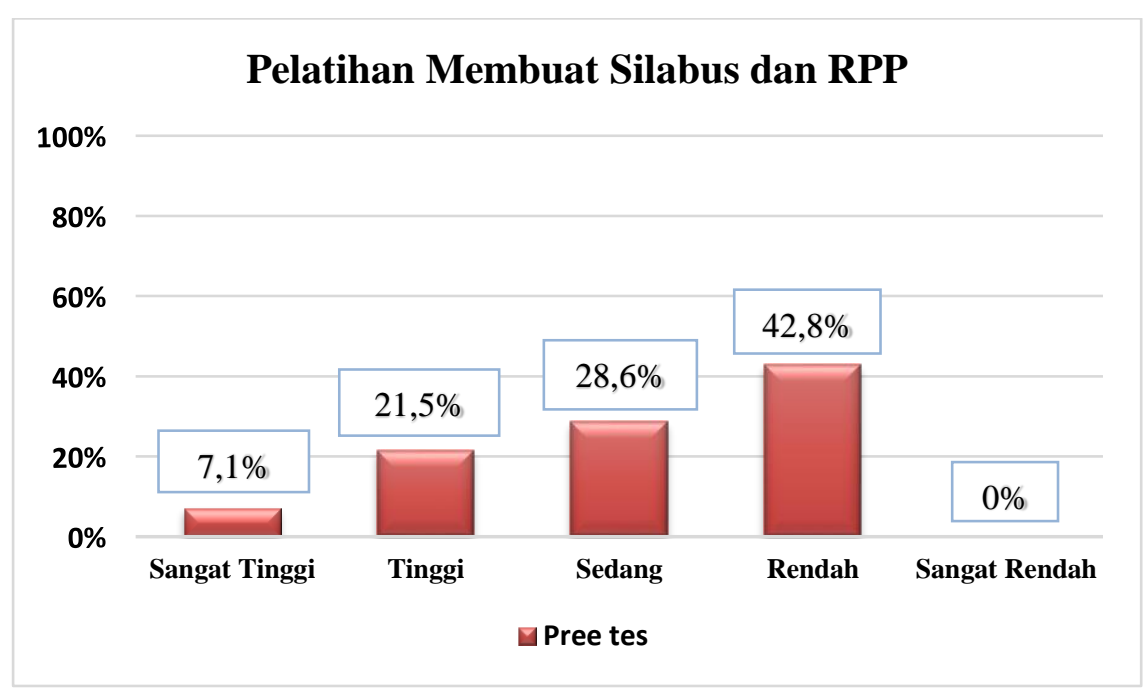

Gambar 1. Diagram Batang Tes Awal 


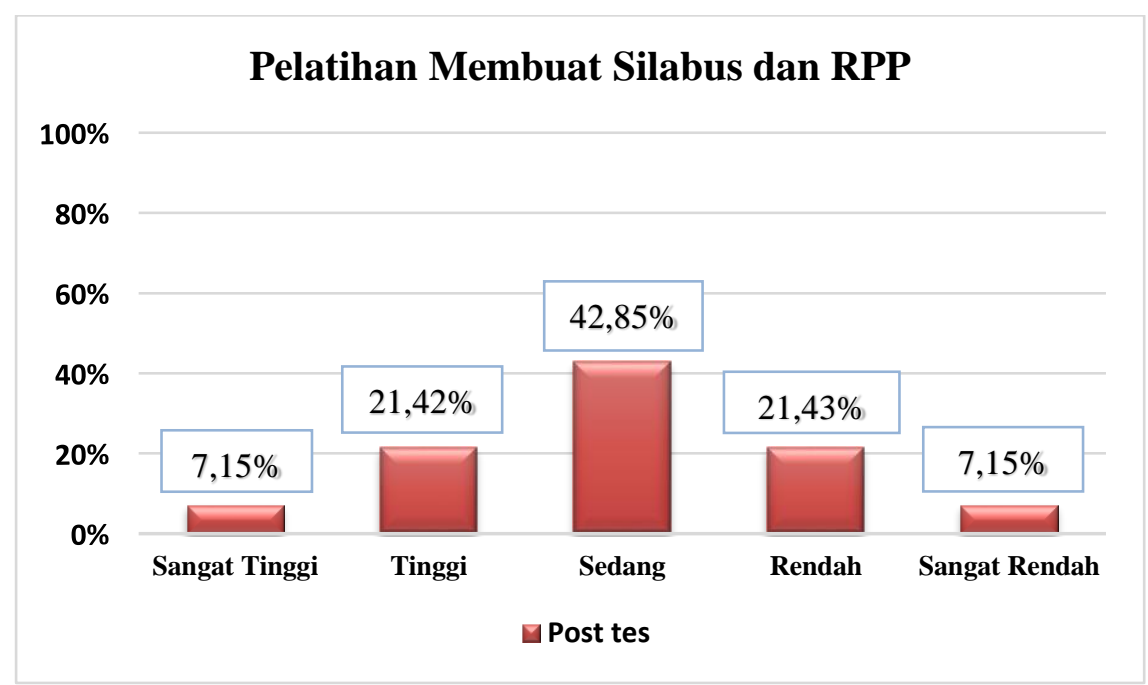

Gambar 2. Diagram Batang Tes Akhir

Dari diagram batang yang telah disajikan terdapat hasil yang meningkat tes awal terlihat hasil rendah yaitu $42,8 \%$ sedangkan dihasil tes akhir terdapat $42,85 \%$ berada dikategori sedang. Partisipan menindaklanjuti pasca pelatihan dengan aktivitas mandiri. Ada sebagian hambatan yang dialami oleh guru di antara lain merupakan (1) sukar mengosongkan waktu buat menyusun/ membetulkan dokumen silabus/ RPP, (2) tidak terdapatnya tuntutan sekolah buat mengimplementasikan kurikulum 2013 secara sempurna, (3) minimnya buku siswa kurikulum 2013 yang bisa diakses siswa, buku tidak bisa dibawa kembali oleh siswa, serta (4) siswa tidak dapat untuk menjajaki kegiatan pendidikan yang ada buku siswa atau buku guru sehingga membuat buku- buku yang ada tidak dapat digunakan sebagaimana mestinya.

\section{KESIMPULAN}

Kesimpulan yang dapat diambil dari kegiatan ini adalah bahwa pelatihan perencanaan pembelajaran dapat berjalan dengan lancar, respon peserta terhadap pelaksanaan pelatihan sangat bagus, terdapat kendala berupa keterbatasan daya dukung sekolah dan kurangnya motivasi guru untuk memperbaiki kualitas perangkat pembelajaran, kendala tersebut diupayakan untuk diatasi dengan terus memberikan pendampingan kepada para guru hingga dihasilkan dokumen silabus dan RPP yang memadai.

Saran yang dapat direkomendasikan adalah pada pelatihan serupa, perlu diupayakan penelitian pendahuluan sejauh mana peserta pelatihan mengimplementasikan kurikulum 2013 di sekolah, pelatihan perlu dikemas dalam bentuk coaching clinic di mana peserta membawa dokumen silabus/RPP yang sudah dipunyai untuk dikaji dan diperbaiki bersama.

\section{UCAPAN TERIMA KASIH}

Ucapan terima kasih kepada ALLAH SWT yang telah memberi kesehatan dan kesuksesan dalam menjalankan kegiatan pelatihan dalam rangka pengabdian kepada masyarakat. Kepada tim pengabdian kepada masyarakat yang telah bekerja sama dalam kegiatan ini, dan menyampaikan terima kasih kepada pihak sekolah khususnya kepada Kepala sekolah juga guru-guru di SMK PGRI 1 Limau yang telah berpartisipasi dalam pelatihan. Saya juga mengucapkan terimakasih terutama kepada Universitas Teknokrat Indonesia yang telah memberikan fasilitas, mendanai, membina, dan memonitor kegiatan ini sehingga dapat berjalan lancar dan mencapai tujuan dengan baik. 


\section{REFERENSI/DAFTAR PUSTAKA}

Amir, A. (2013). Pengembangan profesionalisme guru dalam pembelajaran melalui model lesson study. Logaritma: Jurnal Ilmu-ilmu Pendidikan dan Sains, 1(02).

Fahrizqi, E. B., Aguss, R. M., \& Yuliandra, R. (2021). PELATIHAN PENANGANAN CIDERA OLAHRAGA DI SMA NEGERI 1 PRINGSEWU. Journal of Social Sciences and Technology for Community Service (JSSTCS), 2(1), 11-14.

Fernandes, R. (2019). Relevansi Kurikulum 2013 dengan kebutuhan Peserta didik di Era Revolusi 4.0. Jurnal Socius: Journal of Sociology Research and Education, 6(2), 70-80.

Mulyasa, H. E. (2017). Pengembangan dan implementasi kurikulum 2013.

Nurdiana, A., \& Kirana, A. R. (2017). Workshop Pengembangan RPP dan Silabus Kurikulum 2013 Bagi Guru SMK PGRI 2 Bandar Lampung. Adiguna: Jurnal Pengabdian dan Pemberdayaan Masyarakat, 2(1), 12-15.

Sudirman, S. (2020). Upaya Peningkatan Kompetensi Guru Dalam Menyusun Silabus Dan Rpp Melalui Supervisi Akademik Yang Berkelanjutan Di Sman 1 Simboro Kabupaten Mamuju. Celebes Education Review, 2(2), 81-90.

Sudarsana, I. K. (2018). Optimalisasi penggunaan teknologi dalam implementasi kurikulum di sekolah (persepektif teori konstruktivisme). Cetta: Jurnal Ilmu Pendidikan, 1(1), 8-15.

Sommeng, A. (2019). Peningkatan Kemampuan Guru Dalam Pengembangan Silabus Dan RPP Melalui Pola Pembinaan Profesional Dengan Pendekatan Kooperatif. JIKAP PGSD: Jurnal Ilmiah Ilmu Kependidikan, 3(3), 263-273.

\section{BIOGRAFI PENULIS}

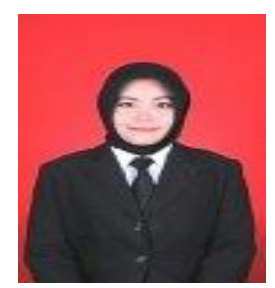

Nama: Rachmi Marsheilla Aguss, S.Pd., M.Pd

Tempat,tanggal lahir: Bandar Lampung, 19 September 1990

Pendidikan: S1 Universitas Lampung, S2 Universitas Negeri Semarang

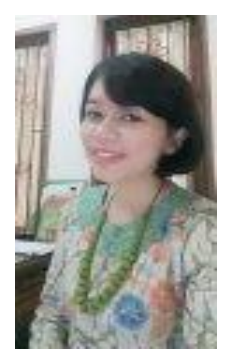

Nama: Dina Amelia

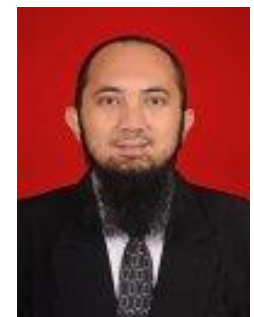

Nama: Zaenal Abidin, S.si, S.Kom., M.T.

Tempat, tanggal lahir: Serang, 10 Juli 1981

Pendidikan: S1 MTK FMIPA Unila, S1 Teknik Informatika STMIK Teknokrat, S2

Informatika STEI ITB 